\title{
Óvoda és nevelés a 21. században
}

\section{Óvodapedagógiai konferencia Nagy József tiszteletére}

Nagyszabású konferencián köszöntötte a pedagógus szakma 85. születésnapján a Szegedi Tudományegyetem Neveléstudományi

Intézetének professzor emeritusát, Nagy Józsefet. A szakmai összejövetelen mintegy 200 óvodapedagógus vett részt az ország különbözó régióiból, szervezốje a Kisrigó-Fészek Alapitvány volt, a

helyszint a szegedi Szent-Györgyi Albert Agóra biztositotta.

A konferencia programjának összeállitása során a szervezók Nagy József professzor elốt tisztelegtek, aki évtizedek óta nagy hatással van az óvodai fejlesztố munkára. A konferencia elóadói Nagy József tanítványai közül kerültek ki, akik munkásságuk során folytatják a kutatásait.

A z első előadásban Józsa Krisztián foglalta össze azokat a kutatásokat, amelyek a DIFER programcsomag (Nagy, Józsa, Vidákovich és Fazekasné, 2004) kidolgozásához kapcsolódnak. Beszélt azokról az előzményekről, melyek Nagy József vezetésével már az 1970-es évektől kezdődően megalapozták a kora gyermekkori fejlesztőmunkát. Áttekintette azokat a kutatásokat, melyek a programcsomag létrehozását megelőzték. Hangsúlyozta a kritériumorientált pedagógiai szemlélet jelentőségét, mely a készségfejlesztő programokban szervesen összeépül a diagnosztikus mérésekkel. A DIFER programcsomag diagnosztikus tesztjeivel óvodáskorban és az első iskolai években feltérképezhető azoknak az alapkészségeknek a fejlettsége, melyek az iskolai tanulás során fontos szerepet játszanak. A kutatások eredményeképpen már több kötetes könyvsorozat készült el, mely az óvodai készségfejlesztés eredményességét segíti (Fazekasné, 2006; Józsa, 2014; Miskolcziné és Nagy, 2006; Nagy, 2009; Zsolnai, 2006). Ezek a módszertani kötetek konkrét javaslatokat, ötleteket adnak arra, hogyan lehet a játékos tevékenységeket, a mesélést a készségfejlesztés szolgálatába állítani. A fejlesztés külön hozadéka, hogy az örömteli tevékenység során a gyermekek elsajátítási motivációja is erősödhet (Józsa, 2005). Az előadás bevezette és keretbe foglalta a konferencia előadásait, melyek mindegyike az óvodáskori fejlesztés egy-egy szegmenséről számolt be. Az előadás írott változata az Iskolakultúra mostani számában olvasható (Józsa, 2016).

Fazekasné Fenyvesi Margit az olvasástanulás és a helyesírás egyik előfeltétel-készségének, a beszédhanghallásnak a fejlesztéséről beszélt. Beszédhanghalláson a beszédhangok tulajdonságainak felismerését, megkülönböztetését, a hangok megfelelő sorrendjének azonosítását értjük. A beszédhanghallás már kora gyermekkorban intenzíven fejlődik, fejlesztése már óvodáskorban eredményes lehet. A DIFER programcsomag beszédhanghallás tesztjével elvégezhető a 4-8 éves gyermekek diagnosztikus felmérése. A beszédhanghallás fejlesztésére rendelkezésre áll olyan óvodai fejlesztőprogram, amely játékos formában a beszédhangok felismerését és megkülönböztetését segíti. A prog- 
ram hatékonysága kísérleti úton igazolt. A kísérlet eredményei alátámasztották, hogy a beszédhanghallás fejlődésén kívül a kísérleti csoportban kimutatható volt a beszédhibák számának csökkenése is. A beszédhanghallás fejlettsége összefügg a helyesírással, ami azt jelenti, hogy a kialakulatlan beszédhanghallással rendelkező gyermekek az iskolában nagy valószínüséggel több helyesírási hibát vétenek. Ez az alapja annak, hogy az 1-4. osztályosok számára beszédhanghallás fejlesztésén alapuló iskolai fejlesztőprogram készült, mely játékos formában, a magyar nyelv és irodalom órák tartalmába integráltan valósítható meg (Fazekasné és Józsa, 2015).

A harmadik előadás témája az óvodások gondolkodásának fejlesztése volt. Zentai Gabriella a rendszerező képesség óvodáskori fejlesztésére mutatott példákat. A rendszerező képesség a gondolkodás egyik alapképessége, az elemi szintje már óvodáskorban kialakul, ez manipulatív müveleteket jelent, így például csoportosítást, válogatást, sorba rendezést. A manipulatív szintre ráépül a képesség fogalmi szintje, ami a fogalmak halmazokba sorolását, sorba rendezését, osztályozását jelenti. A két szint kialakulása

Az óvodások más problémamegoldó módokat választanak, mint az idósebb korosztályba tartozó gyermekek. Az óvodás gyermekek többségére jellemzó, hogy szeretnék megoldani a problémáikat, és úgy érzik, meg is tudják tenni azt. A gyermekek között jelentós egyéni különbségek mutatkoznak a társas prob-

lémák kezelése terén, ezért azoknál a gyermekeknél, akik a többségtól eltérố viselkedési reakciókat produkálnak, a fejlesztésnek nagyon fontos szerepe lenne. A fejlesztés alapfeltétele, hogy minél több információval rendelkezzünk a gyermekek problémamegoldásáról. összefügg egymással, de fejlesztésük más életkorban, más módszerekkel eredményes. $\mathrm{Az}$ elemi rendszerező képesség mérésére készített teszt diagnosztikus kritériumorientált, szemléletében a DIFER programcsomag tesztrendszerébe illeszkedik. Az óvodáskori fejlesztést játékosan, a napi óvodai munkába integráltan javasolt végezni, hogy a játék során átélt öröm fejlesztő hatását is kihasználjuk. Az előadásból a képességfejlesztő program kipróbálására indított kontrollcsoportos kísérlet eredményeit is megismerhettük, amelyet középső csoportos óvodások körében próbáltak ki. A program kifejezetten hatékonynak bizonyult a fejlödésben társaikhoz képest jelentősen megkésett gyermekek esetében (Zentai és Józsa, 2014).

Az óvodai zenei nevelés volt a központi témája Janurik Márta előadásának, aki az óvodai zenei nevelés eredményességéről, a zenei képességek fejlődéséről, a zenei fejlesztés lehetséges transzferhatásairól beszélt. Az éneklés, a zene önmagában fejlesztő hatással van a kisgyermekek kognitív képességeire. A zenei képességek óvodai vizsgálatára készült méröeszköz is a DIFER programcsomagba illik, a zenei észlelés területeit méri, a dallamhallást, harmóniahallást, ritmushallást, hangszínhallást. A zenei képességek fejlesztésének alapját a mindennapos zenei tevékenységek, éneklés, dalosjátékok jelentik (Janurik és Józsa, 2012). A fejlesztés nem igényli zenei képzettségű pedagógus közremüködését. Az előadásból azt is megtudhattuk, hogy a zenei képességek fejlesztésének az elemi alapkészségekre vonatkozó transzferhatása is van (Janurik és Józsa, 2016).

A mesék világába vezetett be Nyitrai Ágnes (2016) előadása, aki arról beszélt, hogyan lehet a meséket, a mesélést, a mesékhez kapcsolódó beszélgetéseket az óvodai fejlesztés szolgálatába állítani, az előadás írott változata ebben a lapszámban olvasható. A mesélés, 
mesehallgatás az eredményes szocializációt segíti elő. A mesélés már a kisgyermekkori kognitív és érzelmi fejlődés során fontos szerepet játszik. A mesékhez kapcsolódó beszélgetés a kognitív és a szociális kompetencia fejlődését egyaránt segítheti. A DIFER készségek közül több is fejleszthető a mesékről való tematikus beszélgetés során: relációszókincs, következtetés, összefüggés-megértés. A fejlesztés módszere az lehet, ha a napi rendszerességgel zajló beszélgetések során a mesékből kiemelt összefüggések tartalmát megbeszélik a pedagógusok a gyermekekkel (Nyitrai és Darvai, 2013).

Kasik László az óvodások társas problémáiról beszélt. Kérdőíves vizsgálatában óvodások szüleit és óvodapedagógusait kérdezte meg arról, hogy milyen társas problémái vannak az óvodásoknak, és azok megoldására milyen módokat választanak. Az óvodások más problémamegoldó módokat választanak, mint az idősebb korosztályba tartozó gyermekek. Az óvodás gyermekek többségére jellemző, hogy szeretnék megoldani a problémáikat, és úgy érzik, meg is tudják tenni azt. A gyermekek között jelentős egyéni különbségek mutatkoznak a társas problémák kezelése terén, ezért azoknál a gyermekeknél, akik a többségtöl eltérő viselkedési reakciókat produkálnak, a fejlesztésnek nagyon fontos szerepe lenne. A fejlesztés alapfeltétele, hogy minél több információval rendelkezzünk a gyermekek problémamegoldásáról. Az előadó arra is utalt, hogy a gyermekek által átélt események hatása évekkel később is megjelenhet a szociális problémamegoldásukban (Kasik és Gál, 2014).

Az előadások betekintést nyújtottak a kisgyermekkori személyiségfejlődésbe, rávilágítottak arra, hogy a korai fejlesztésnek milyen fontos szerepe van a későbbi iskolai sikerességben. Rámutattak az óvodai készségfejlesztésben rejlő óriási lehetőségekre. Az előadásokat átható szemlélet alapjait Nagy József rakta le évtizedekkel ezelőtt, az általa elindított munkának napjainkban már a gyakorlatban is egyértelmüen érezhető, megkérdőjelezhetetlen hatása van.

\section{Köszönetnyilvánítás}

A beszámoló és az elhangzott elöadások többsége az OTKA K83850 pályázathoz kapcsolódik.

\section{Irodalomjegyzék}

Fazekasné Fenyvesi Margit (2006): A beszédhanghallás fejlesztése 4-8 éves életkorban. Mozaik Kiadó, Szeged.

Fazekasné Fenyvesi Margit és Józsa Krisztián (2015): Az elmélet és a gyakorlat szintézise a fejlesztő programokban: a beszédhanghallás készsége. Neveléstudomány: Oktatás - Kutatás - Innováció, 3. 1. sz. 64-76.

Janurik Márta és Józsa Krisztián (2012): Findings of a three months long music training programme. Hungarian Educational Research Journal, 2. 4. sz. DOI: $10.5911 /$ herj2012.04.01

Janurik Márta és Józsa Krisztián (2016): A zenei képességek összefüggése a DIFER készségekkel óvodáskorban. Neveléstudomány: Oktatás - Kutatás Innováció, 4. 1. sz. 49-69.
Józsa Krisztián (2005): A képességek és motívumok kölcsönös fejlesztésének lehetősége. In: Kelemen Elemér és Falus Iván (szerk.): Tanulmányok a neveléstudomány köréböl. Müszaki Könyvkiadó, Budapest. 283-302.

Józsa Krisztián (2014): A számolás fejlesztése 4-8 éves életkorban. Mozaik Kiadó, Szeged.

Józsa Krisztián (2016): Kihívások és lehetőségek az óvodai fejlesztésben. Iskolakultúra, 26. 4. sz. (jelen kötetben)

Kasik László és Gál Zita (2014): Óvodások szociálisprobléma-megoldó gondolkodása szüleik és pedagógusaik véleménye alapján. Magyar Pedagógia, 114 3. sz. 189-213.

Miskolcziné Radics Katalin és Nagy József (2006): Az irásmozgás-koordináció fejlesztése 4-8 éves életkorban. Mozaik Kiadó, Szeged. 
Nagy József (2009, szerk.): Fejlesztés mesékkel: Az anyanyelv, a gondolkodás fejlödésének segitése mesékkel 4-8 éves életkorban. Mozaik Kiadó, Szeged.

Nagy József, Józsa Krisztián, Vidákovich Tibor és Fazekasné Fenyvesi Margit (2004): DIFER Programcsomag: Diagnosztikus fejlödésvizsgáló és kritériumorientált fejlesztő rendszer 4-8 évesek számára. Mozaik Kiadó, Szeged.

Nyitrai Ágnes (2016): Mese és mesélés: A mesék alkalmazásának lehetőségei a kritériumorientált fejlő- déssegítésben. Iskolakultúra, 26. 4. sz. (jelen kötetben)

Nyitrai Ágnes és Darvai Sarolta (2013): A mese és a játék jelenléte a kisgyermekes családok életében. Iskolakultúra, 23. 11. sz. 73-85.

Zentai Gabriella és Józsa Krisztián (2014): Óvodás gyermekek gondolkodási képességének fejlesztése: egy fejlesztő program módszerei és eredményei. $\mathrm{Fej}$ lesztö Pedagógia, 25. 3. sz. 9-14.

Zsolnai Anikó (2006): A szocialitás fejlesztése 4-8 éves életkorban. Mozaik Kiadó, Szeged. 